\title{
Teaching
Methods
}

\section{Merging the Roles of Learning, Research, and Outreach in a Nursery Irrigation Exercise}

\author{
Geno A. Picchioni ${ }^{1,5}$, Jagtar Singh², John G. Mexal ${ }^{3}$, \\ and Ryan M. Goss ${ }^{4}$
}

\begin{abstract}
ADDITIONAL INDEX WORDS. evapotranspiration, crop coefficient, Fallugia paradoxa, apache plume, Lonicera japonica, japanese honeysuckle, visual analogy, industry collaboration

SuMMARY. The authors used a simple procedure to teach how to generate evapotranspiration (ET) data for both 1- and 5-gal pots of the xeric shrub apache plume (Fallugia paradoxa) and the mesic vine japanese honeysuckle (Lonicera japonica 'Halliana'). In-class instruction and assigned reading prepared students for collecting data over a 22-day period ( 12 Apr. to 3 May), processing data on an electronic spreadsheet, accessing the Internet to acquire reference plant ET data, calculating a crop coefficient $\left(\mathrm{K}_{\mathrm{c}}\right)$, preparing graphs, organizing a digital presentation, and presenting the findings to commercial nursery participants and instructors. When averaged across days and pot sizes, ET of japanese honeysuckle was $1.22 \mathrm{~cm} \cdot \mathrm{d}^{-1}$, whereas ET of apache plume was only $0.80 \mathrm{~cm} \cdot \mathrm{d}^{-1}$. This finding supported the students' hypothesis that a nursery block of potted mesic vines would use more water than a nursery block of potted xeric shrubs per unit of ground area. Commercial nursery participants adopted the ET monitoring technique after viewing the student presentation, indicating effective transfer of information by the students. The simple, inexpensive, 3 -week exercise furthered the students' horticulture knowledge and comprehension while allowing for a collaborative effort with the local nursery industry.
\end{abstract}

Department of Plant and Environmental Sciences, New Mexico State University, Box 30003, Las Cruces, NM 88003

This work was supported by the New Mexico Agricultural Expt. Station.

We thank Jeff Harvey, Nora White, and Lance Harkey of Sunland Nursery, Inc., Mesilla Park, N.M., for the loan of plant material and their time and consideration provided at the nursery and in the classroom. We also thank Joanna Blackwood, Gwen Dominguez, Cynthia Howell, and Jessica Roderick for technical support.

Mention of a trademark, proprietary product, or vendor does not constitute an endorsement by New Mexico State University, or approval to the exclusion of other products or vendors that may also be suitable.

\section{${ }^{1}$ Associate Professor.}

${ }^{2}$ Graduate Teaching Assistant.

${ }^{3}$ Professor.

${ }^{4}$ Assistant Professor.

${ }^{5}$ Corresponding author. E-mail: gpicchio@nmsu.edu.

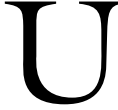
ndergraduate students generally have difficulty understanding plant water use in nursery conditions. A simple and reliable exercise to quantify evapotranspiration (ET) of containerized nursery plants is missing in the literature and could improve students' understanding of basic irrigation scheduling concepts. As potential nursery managers, students need to understand the consequences of both under- and overwatering a nursery crop.

Container production nurseries in the southwestern United States require significant amounts of water. In xeric environments, essentially all water demands must be met by irrigation, with little or no water from natural precipitation to support production. The northern Chihuahuan Desert in southern New Mexico provides an excellent "real-life" instructional setting for nursery production in high evaporative demand conditions (Picchioni et al., 2001).

Southwestern United States nursery managers have economic, environmental, and plant management concerns about water usage. If they apply less water than crops need, they might compromise product quality and prolong time of production (Beeson, 2006). Conversely, if they apply more water than required, they waste water and electricity, increase nutrient losses to the environment through surface runoff, and may limit growth and transplant survival (Beeson, 2006; Fare et al., 1992; Franco et al., 2006)

The main objective of this exercise was to improve student understanding of nursery plant water use and irrigation scheduling through a collaborative study with a local wholesale nursery. This paper supports instructors who wish to teach nursery crop water use measurement, but who have limited experience in quantitative irrigation methods. We designed the exercise to engage students in not only active learning, but

\begin{tabular}{llll}
\hline $\begin{array}{l}\text { Units } \\
\begin{array}{l}\text { To convert U.S. to SI, } \\
\text { multiply by }\end{array}\end{array}$ & U.S. unit & SI unit & $\begin{array}{l}\text { To convert SI to U.S., } \\
\text { multiply by }\end{array}$ \\
\hline 0.3048 & $\mathrm{Ft}$ & $\mathrm{m}$ & 3.2808 \\
0.0929 & $\mathrm{ft}^{2}$ & $\mathrm{~m}^{2}$ & 10.7639 \\
3.7854 & gal & $\mathrm{L}$ & 0.2642 \\
2.5400 & inch(es) & $\mathrm{cm}^{2}$ & 0.3937 \\
6.4516 & inch $^{2}$ & $\mathrm{~cm}^{2}$ & 0.1550 \\
16.3871 & inch & $\mathrm{cm}^{3}$ & 0.0610 \\
0.4536 & $\mathrm{lb}$ & $\mathrm{kg}$ & 2.2046 \\
0.5933 & $\mathrm{lb} / \mathrm{yard}^{3}$ & $\mathrm{~kg} \cdot \mathrm{m}^{-3}$ & 1.6856 \\
1.6093 & mile(s) & $\mathrm{km}$ & 0.6214 \\
28.3495 & $\mathrm{oz}$ & $\mathrm{g}$ & 0.0353 \\
& & &
\end{tabular}


also in research and outreach, while teaching water use measurements.

Intended outcomes of the exercise were as follows:

- Conduct a nursery pot study to teach plant water use measurement while reinforcing skills in data collection and organization, graphing, interpretation, and information retrieval from the Internet.

- Include a pedagogical foundation of rationale for the metric system, assigned readings, the scientific method, and hypothesis testing.

- Engage students with commercial nursery managers through outreach designed to present results and recommendations to a client.

-Integrate a student-researcher role with the learning and outreach components.

\section{Materials and methods}

This exercise was designed for an upper division ornamental plant production and management course at New Mexico State University (NMSU) in the Spring 2006 semester, and was completed between 11 Apr. and 3 May. The course has an average enrollment of 18 students, although as few as four students can complete this exercise. About $25 \%$ of total lecture, laboratory, and final exam time was used to complete the project, which augmented lectures on nursery water issues while comprising the only laboratory activity during a 3 -week period. The exercise considered irrigation scheduling, acquisition of weather data, ET at the simplest level of a single pot, relationship between a gravimetric measure to equivalent depth of water, and the intrinsic value of a crop coefficient $\left(\mathrm{K}_{\mathrm{c}}\right)$. The $\mathrm{K}_{\mathrm{c}}$ adjusts irrigation volume to season, current weather conditions, crop developmental stage, and specific crop production practices. An established $K_{c}$ is therefore a permanent irrigation scheduling and "metering" tool for the grower.

Two instructors plus a graduate teaching assistant guided the class members through the project. Three commercial nursery participants included the business, production, and integrated plant health managers at Sunland Nursery (Mesilla Park, N.M.). The nursery participants hosted the students during two trips to their nursery. The nursery participants also attended a live student presentation at the end of the project.
The following arrangements and supplies were specific to this project and can be modified as necessary to meet an instructor's needs.

- Background reading material (see Al-Jamal et al., 2002; Beeson, 2006; Glenn et al., 1998; Saucedo et al., 2006)

- Commercial nursery and employees willing to collaborate and loan plants

- Field space to simulate outdoor nursery conditions

- Potted plants (in this case, 25 5 -gal pots per species and $36 \mathrm{l}$-gal pots per species)

- Electronic balance (battery operated), 20-kg capacity

- Wood pallets for pot support and uninterrupted drainage after irrigation

- Irrigation source and handwatering system with hose

- Labeling stakes

- Blank data sheets

- Laptop computer

- Access to Internet and automated weather station

- Electronic spreadsheet, graphics, and presentation software

Established 1- and 5-gal apache plume seedlings and vegetatively propagated japanese honeysuckle were transported from Sunland Nursery to the Fabian Garcia Science Center (FGSC) on the NMSU Las Cruces campus, $\approx 6$ miles from the nursery. Both species were in a state of active growth, of excellent quality, and nearing the end of production. The xeric apache plume, indigenous to the Chihuahuan Desert, and the mesic japanese honeysuckle were expected to have different water use characteristics. The growing medium was a coarse mixture of $77 \%$ aged pine bark, $3 \%$ fine sand, and $20 \%$ crushed pecan shells (by volume). The medium was premixed with $10.7 \mathrm{lb} /$ yard $^{3}$ Apex $18 \mathrm{~N}-2.6 \mathrm{P}-10 \mathrm{~K}$ slow-release fertilizer (J.R. Simplot Co., San Diego), $2.7 \mathrm{lb} /$ yard $^{3}$ ProMate Power Verde micronutrient blend fertilizer ( $\mathrm{Hel}-$ ena Chemical Co., Collierville, Tenn.), and $5.3 \mathrm{lb} /$ yard $^{3}$ composted sewage sludge from the city of Las Cruces, N.M., sewage treatment plant. According to the Sunland Nursery integrated plant health manager, the nursery irrigated apache plume and japanese honeysuckle every other day between 11 Apr. and 3 May.
For both species, there were thirty-six 1-gal pots and twenty-five 5 -gal pots, with a 1 -gal-size canopy width averaging 20 to $30 \mathrm{~cm}$ and a 5 -gal-size canopy width averaging 40 to $50 \mathrm{~cm}$, depending on the species. For apache plume, heights from the ground to the top of the canopy averaged 0.3 and $0.4 \mathrm{~m}$ for $1-$ and 5 -gal sizes respectively, whereas the heights of japanese honeysuckle canopies (supported by 1 -inch ${ }^{2}$ wooden stakes) averaged 1.0 to $1.6 \mathrm{~m}$ for 1 - and 5-gal sizes respectively. The plants were organized by pot size and species into four blocks and placed atop wooden pallets at the FGSC. The outer perimeters of the $5 \times 5$-pot 5-gal-size blocks and $6 \times$ 6-pot 1-gal-size blocks were not included in data collection and provided a barrier against border effects on the inner study pots. Study pots (nine 5 -gal pots in a $3 \times 3$-pot square; sixteen 1 -gal pots in a $4 \times 4$-pot square) were given unique numbers to allow tracking of daily ET of individual pots. Pot spacing was similar to that at Sunland Nursery for nearmarket stage for these species. A nylon cord was tied around the perimeter canopies of the tall japanese honeysuckle plants to prevent pots from falling over during windy weather.

Ground area was determined by multiplying the lengths of the two sides of a given block from the outer edges of the corner pots, and excluding the perimeter pots. The resulting ground areas were $0.54 \mathrm{~m}^{2}$ for 1 -galsize apache plume, $0.42 \mathrm{~m}^{2}$ for 1 -galsize japanese honeysuckle, $0.91 \mathrm{~m}^{2}$ for 5 -gal-size apache plume, and $0.74 \mathrm{~m}^{2}$ for 5-gal-size japanese honeysuckle.

A class period was used for initial training on pot weighing procedure, after which time student pairs assumed responsibility for pot weighing and watering. On 11 Apr., each pot was thoroughly watered by hand to induce leaching, and then allowed to drain for about $20 \mathrm{~min}$. The weight after drainage was defined as the pot capacity weight. From 12 Apr. to 3 May, pots were weighed during the late afternoon before watering thoroughly to replace the previous day's ET. On 3 May, a final pot capacity weight was obtained for each study block, which, on average, was within $3.4 \%$ of the 11 Apr. pot capacity weight. Because of constant pot capacity weights during the short 
3-week exercise, students used the 11 Apr. pot capacity weights for a baseline well-watered plant.

Students learned how to enter pot weight data onto an electronic spreadsheet (Fig. 1; sample calculations) to estimate daily water use of each pot, using Excel (2003 Professional Version; Microsoft Corp., Redmond, Wash.). Before daily watering, the pot weight was subtracted from the pot capacity weight to provide kilograms of ET per pot per day (Fig. 1, cells D17-D32). The daily ET per pot was averaged across the study block (cell D33), copied to cell B6, multiplied by 1000 to provide grams of water (equivalent to cubic centimeters of volume, cell C6), and multiplied by the number of pots in the block to determine total volume of ET from the study block (cell D6). Total ET volume per block was divided by the area (square centimeters in cell E6) to calculate the equivalent depth (centimeters) of daily ET from the block (cell F6).

Availability of reference plant ET is essential for establishing $\mathrm{K}_{\mathrm{c}}$ for a containerized plant (Saucedo et al., 2006). If a nursery crop's water use can be empirically determined, nearby automated weather station real-time data can be used to establish a $\mathrm{K}_{\mathrm{c}}$. We used the New Mexico Climate Center (NMCC) website (New Mexico Climate Center, 2006), the FGSC weather station $(\approx 100 \mathrm{~m}$ from the study site), and clipped grass for the reference plant $\mathrm{ET}\left(\mathrm{ET}_{\mathrm{o}}\right)$. The $\mathrm{ET}_{\mathrm{o}}$ data in columns $\mathrm{G}$ and $\mathrm{H}$ of Fig. 1 were obtained directly from the NMCC website, which used the standardized Penman-Monteith equation of the American Society of Civil Engineers (2005). Students downloaded $\mathrm{ET}_{\mathrm{O}}$ by the method of Ruiz et al. (2006). Downloaded ET o was in inches (Fig. 1, cell G6), which was converted to centimeters of depth
(Fig. 1, cell H6) to match the metric unit for ET depth of the nursery plants (Fig. 1, cell F6). The $\mathrm{K}_{\mathrm{c}}$ was then calculated as the ratio of ET for the plant of interest (centimeters) to $\mathrm{ET}_{\mathrm{o}}$ (centimeters), and placed in cell I6 (Fig. 1).

Students prepared a live 30min presentation using PowerPoint (2003 Professional Version; Microsoft Corp.). Each student selected a specific component of the presentation to prepare and present. The students plotted the data using Excel, and their finished plots were exported into the PowerPoint presentation. For the purpose of this paper, we subsequently replotted all data on SigmaPlot (version 8.02a; Systat Software, Richmond, Calif.). The 30-min student presentation was made on the final examination day and was attended by the three Sunland Nursery, managers, instructors, and teaching assistant. After the presentation, a

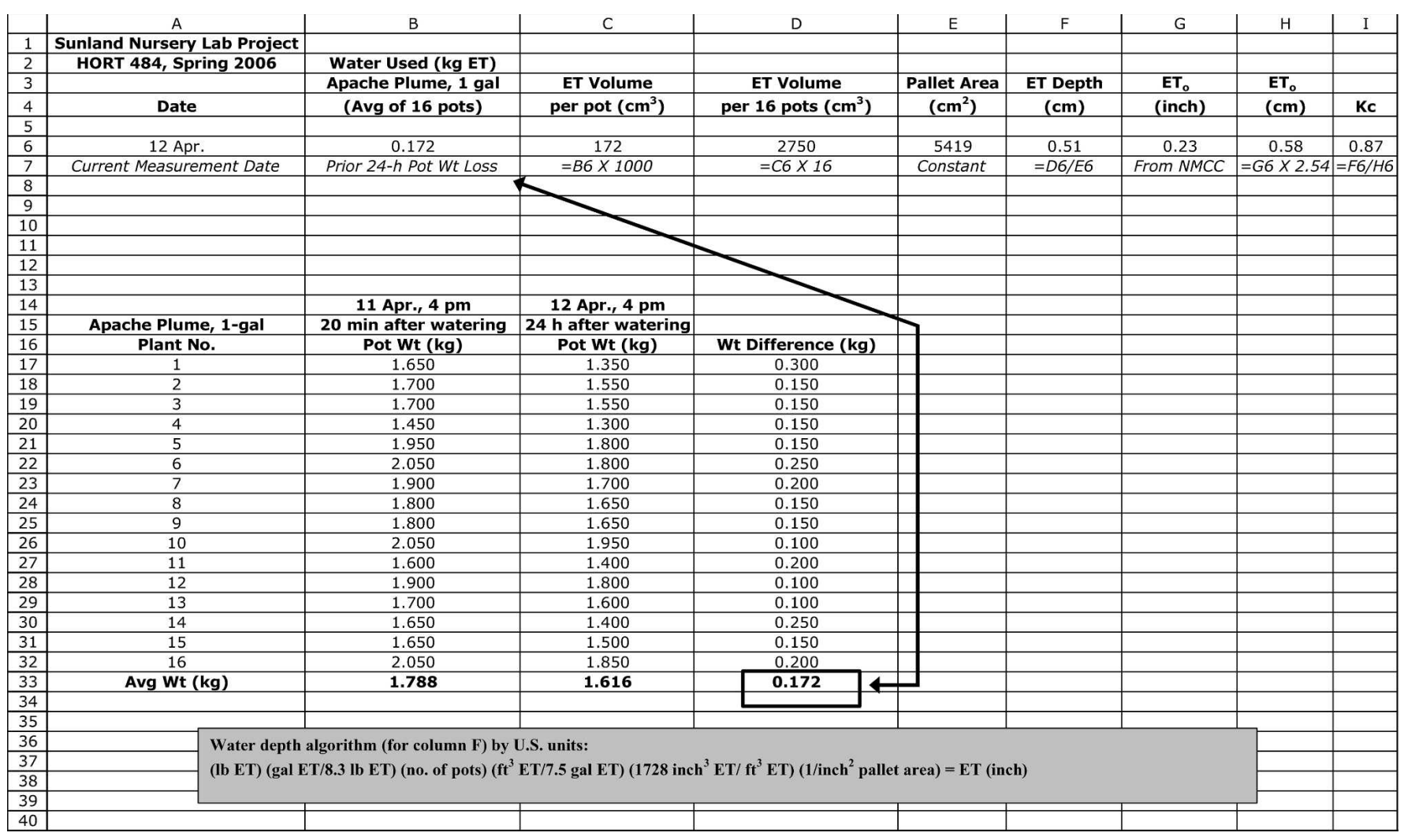

Fig. 1. A partial electronic spreadsheet showing sample calculations for 1 -gal-size apache plume during the first day of the study (11 Apr. to 12 Apr.). The cells in row 6 show current date, the average water use [evapotranspiration (ET)] in weight (kilograms) for 16 pots, and formulae for converting kilograms water use per pot to volume of water use per pot in cubic centimeters, volume of water use for all 16 pots in cubic centimeters, depth of water use per area covered by all pots in centimeters, reference ET in centimeters $\left(E T_{o}\right)$, and the crop coefficient $\left(K_{c}\right)$. For convenience, italicized cell formulae and descriptive information are shown in row 7 , and the method for determining average pot water use for $1 \mathrm{~d}$, using $11 \mathrm{Apr}$. to 12 Apr. as an example, is in rows 14 to 33. By comparison, an algorithm for converting weight of ET to depth of ET in U.S. units is provided in the shaded box at the bottom of the figure $\left(1 \mathrm{~kg}=2.2046 \mathrm{lb} ; 1 \mathrm{~cm}^{3}=0.0610 \mathrm{inch}^{3} ; 1 \mathrm{~cm}^{2}=0.1550 \mathrm{inch}^{2}\right.$; $1 \mathrm{~cm}=0.3937$ inch). 
panel discussion for questions and answers ensued for $\approx 30 \mathrm{~min}$. After the panel discussion, the instructors determined whether the exercise accomplished the objectives, proposed modifications to improve effectiveness of the exercise, and discussed how well students functioned in the combined roles of learners, researchers, and teachers.

\section{Results and discussion}

Pot study. Because of the relatively broad and short shrubby profile of xeric apache plume and a tall linear profile of mesic japanese honeysuckle, the students hypothesized that potted apache plume would have a smaller water requirement than potted japanese honeysuckle per unit ground area and under identical environmental conditions. There were similar patterns across time for ET per pot among the four study blocks (Fig. 2). The means in Fig. $2( \pm$ SE) were calculated as in Fig. 1. In 1-gal pots, the overall ET per pot averaged only $8 \%$ higher in japanese honeysuckle than in apache plume (Table 1 ). In the 5-gal pots, individual pot water use of japanese honeysuckle averaged $36 \%$ more than that of apache plume (Table 1). The species difference in ET per pot, particularly in the 5-gal
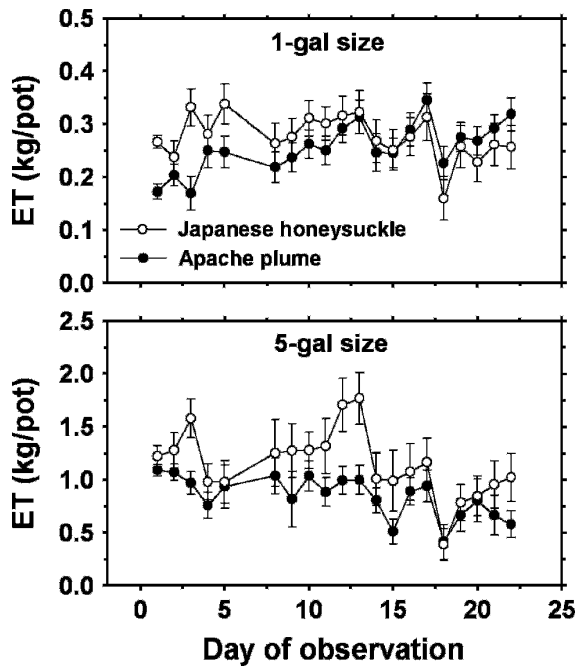

Fig. 2. Daily evapotranspiration (ET) of apache plume and japanese honeysuckle expressed as kilograms per pot $(1 \mathrm{~kg}$ of water $=1 \mathrm{~L})$ during the 22-d study (12 Apr. to 3 May). Each value is the average \pm SE of sixteen 1 -gal pots or nine 5-gal pots, determined as shown in sample calculations of Fig. 1 (1 kg = 2.2046 lb; $1 \mathrm{~L}=0.2642$ gal). size, carried over to differences in ET depth and $K_{c}$, and was likely attributable to a larger projected leaf area of the relatively tall japanese honeysuckle vines, the xeric nature of apache plume shrubs, and leaf size. Apache plume has deeply lobed leaves that reach 0.75 inch in length, whereas japanese honeysuckle has leaves up to 3 inches long and entire margins.

As expected, daily ET per pot increased with the pot size for a given species, almost in proportion to surface area (Table 1, Fig. 2). A 5-gal container has a fourfold greater surface area than a l-gal container, and should have four times the ET. On average, ET per pot for apache plume in the 5-gal size was 3.2 times higher than in the 1 -gal size, and 4.1 -fold

Table 1. Overall averages for daily evapotranspiration (ET) per pot, daily ET depth, and daily crop coefficient $\left(\mathrm{K}_{\mathrm{c}}\right)$ of apache plume and japanese honeysuckle across the 22-d observation period (12 Apr. to 3 May).

\begin{tabular}{lcccc}
\hline Species & $\begin{array}{c}\text { Pot size } \\
(\mathbf{g a l})^{\mathbf{z}}\end{array}$ & ET $(\mathrm{kg} / \mathrm{d} / \mathrm{pot})^{\mathrm{z}}$ & ET $\left(\mathbf{c m} \cdot \mathbf{d}^{-\mathbf{1}}\right)^{\mathrm{z}}$ & $\mathbf{K}_{\mathbf{c}}$ \\
\hline Apache plume & 1 & $0.26 \pm 0.01$ & $0.76 \pm 0.03$ & $1.19 \pm 0.06$ \\
Japanese honeysuckle & 5 & $0.84 \pm 0.04$ & $0.84 \pm 0.04$ & $1.31 \pm 0.08$ \\
& 1 & $0.28 \pm 0.01$ & $1.05 \pm 0.04$ & $1.65 \pm 0.07$ \\
& 5 & $1.14 \pm 0.07$ & $1.38 \pm 0.09$ & $2.15 \pm 0.14$ \\
\hline
\end{tabular}

${ }^{\mathrm{z}} \mathrm{gal}=3.7854 \mathrm{~L} ; \mathrm{l} \mathrm{kg}=2.2046 \mathrm{lb} ; \mathrm{l} \mathrm{cm}=0.3937$ inch.

Each value is the mean \pm SE of 20 daily averages (from Figs. 2 and 3), with each day comprising sixteen 1 -gal pots or nine 5-gal pots.

ET, evapotranspiration; $K_{c}$, crop coefficient.

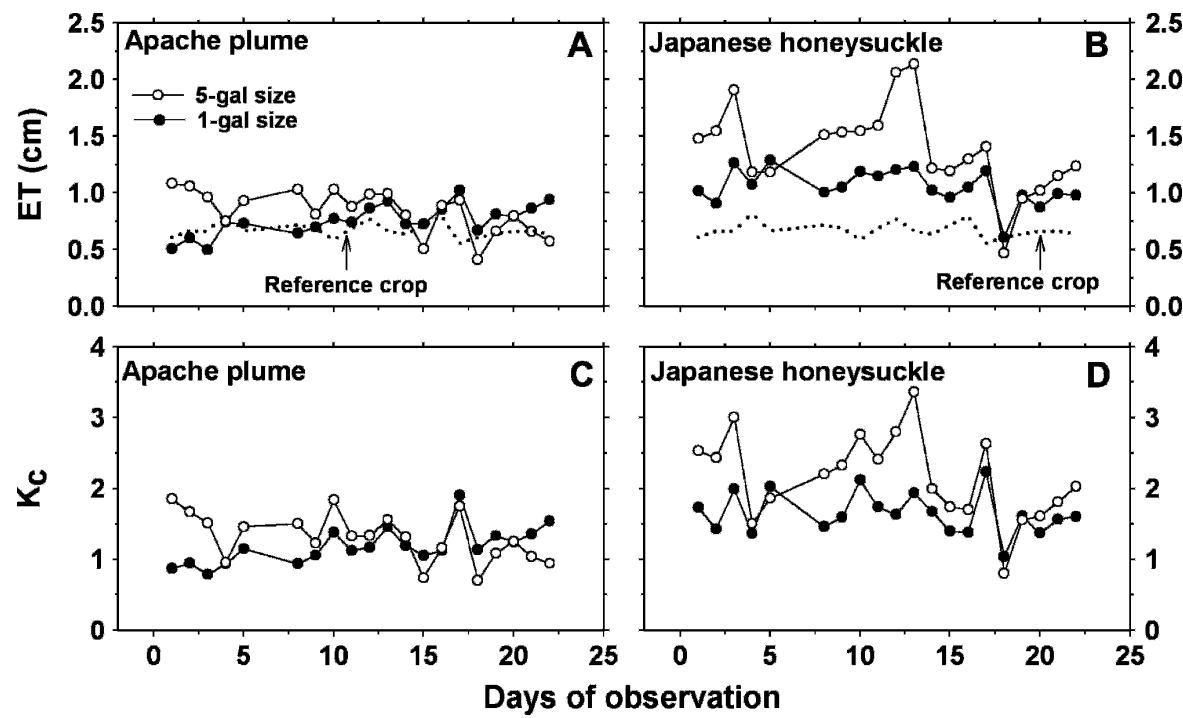

Fig. 3. (A-D) Daily evapotranspiration (ET) of apache plume, japanese honeysuckle, and the reference plant of clipped grass (dashed line) expressed as depth (centimeters) of water $(A, B)$, and the dimensionless crop coefficient $\left(K_{c}\right)$ of apache plume and japanese honeysuckle $(C, D)$ during the 22-d study (12 Apr. through 3 May). Each value is the average of sixteen 1 -gal pots or nine 5 -gal pots $(1 \mathrm{~cm}=0.3937 \mathrm{inch} ; 1 \mathrm{~L}=0.2642 \mathrm{gal})$. 
ET did not change consistently in relation to the nursery crop ET, as should be expected (Fig. 3A and B). The decrease in nursery plant ET on day 18 may have been incited by inadequate watering. The higher daily ET in 5-gal vs. 1-gal pot sizes along with the higher daily ET of japanese honeysuckle compared with apache plume (all noted in Fig. 3A and B) translated to identical differentials when factoring in the corresponding daily $\mathrm{ET}_{\mathrm{o}}$ as a constant to derive the $\mathrm{K}_{\mathrm{c}}$ (Fig. 3C and D). The $\mathrm{K}_{\mathrm{c}}$ in 1-gal pots averaged 1.19 for apache plume and 1.65 for japanese honeysuckle, whereas in the 5 -gal pots, $\mathrm{K}_{\mathrm{c}}$ averaged 1.31 for apache plume and 2.15 for japanese honeysuckle (Table 1).

Average $\mathrm{K}_{\mathrm{c}}$ for nursery crops in the current exercise (Table l) pertain to relatively cool spring days but equaled or exceeded summer maximum $\mathrm{K}_{\mathrm{c}}$ values of many field crops. The mean japanese honeysuckle $\mathrm{K}_{\mathrm{c}}$ values (1.7-2.2) were among the highest that we found in the semiarid agriculture literature. More research to reveal a full-season $\mathrm{K}_{\mathrm{c}}$ curve may disclose even higher $K_{c}$ values for japanese honeysuckle, apache plume, and other nursery crops.

LESSONS IN DATA COLLECTION. Weighing and watering potted plants requires modest technical skills and instrumentation. However, to complete the assignment, these tasks required students to coordinate their group visitation to the study site for about one-third of their afternoons on a minimum of $3 \mathrm{~d}$ per week. Because of time needed to complete this activity, students learned firsthand why $\mathrm{K}_{\mathrm{c}}$ values for most containerized crops have yet to be established (Mathers et al., 2005). During the presentation, students also acknowledged that because of the semester time constraint, their exercise fell short of a publishable effort that reports the seasonal variation in $\mathrm{K}_{\mathrm{c}}$ plotted against accumulated growing degree days (Saucedo et al., 2006).

The instructors had few expectations concerning level of variability, but later learned that variability in daily pot weight change is the biggest technical issue to overcome. The small sample size ( $\mathrm{n}=9$ or 16 pots) was helpful to this exercise, but average $\mathrm{CV}$ across the study was as high as $61 \%$, depending on the study block. High variability was likely the result of systematic error in weighing, and in achieving a consistent level of pot saturation after watering, especially for the 5-gal pots. The high variability may be overcome by increasing numbers of pots, more practice, and maintaining attention to details, which would increase requirements for either space or time. We also agreed that periodic stoppages of data collection would permit the reviewing of variability in pot weight change data that could, in turn, help determine whether the "attention-to-detail" factor is being adequately addressed by students.

Lessons In PEDAgogy. Teachers urge use of the metric system in the curriculum, but the junior-senior student participants in this exercise were initially apprehensive about metrics. Also, the nursery participants favored U.S. units over metric. After several lectures, students grew more comfortable with the units of kilograms, centimeters, square centimeters, and cubic centimeters. For the metric units, three multiplication or division steps were needed to convert kilograms of ET to equivalent ET depth in centimeters (Fig. 1). Five multiplication or divisions steps would be needed to convert pounds of ET to inches of ET (Fig. 1).

Assigned readings were pertinent to the student project, particularly that of a recent study at FGSC (Saucedo et al., 2006) that involved the native and xeric Chihuahuan Desert evergreen shrub creosote (Larrea tridentata). In that study, creosote was grown in a study block of twelve 5 -gal pots for a 240 -d season (years 2002-03), with the same reference crop and experimental procedures used in the current exercise. The instructors aided in the construction of a comparative figure (Fig. 4). The 22 -d average $K_{c}$ values of the nursery crops studied in the current exercise (5-gal size, from Table 1) were positioned in boxes, with day of the year on the $\mathrm{x}$-axis, as reported in Saucedo et al. (2006). Saucedo et al. (2006) had a maximal day-to-day change in $\mathrm{K}_{\mathrm{c}}$ of 0.3 to 0.4 units (Fig. 4). Between consecutive days in the current short-term study, $\mathrm{K}_{\mathrm{c}}$ of apache plume changed by as much as a full unit, and $\mathrm{K}_{\mathrm{c}}$ of japanese honeysuckle changed by as much as 1.5 to 2 units (Fig. 3C and D). The higher day-today change in the current exercise may reflect inexperience of the individual students as well as variability between student groups.

This exercise lacked predetermined outcomes, and the "unknown" element supported the scientific method, motivational learning, and inquisition among students (Picchioni et al., 2000). The hypothesis that the mesic japanese honeysuckle would have a higher ET than the xeric apache plume was supported by limited background reading on natural history (Dirr, 1990; Lamb, 1975), intuition, and the resulting data. A simple hypothesis at face value became more complicated as the students learned that quantitative water use data are essential to determine how much a tall canopy of a mesic species would accentuate water demand above that of a xeric shrub. Consequently, the students grew critical of qualitative or anecdotal watering guidelines often found in horticultural references.

The scientific level of this exercise could be increased. For example, rationale for nursery irrigation decision making is based on crop need driven by plant water relations and by crop and soil water depletion; both can be taught using Web-based technology. Inclusion of experimental statistics could determine a costeffective number of pots for detecting water use variation between species and pot sizes. More challenging graphing assignments could enhance student critical thinking skills (Leonard and Patterson, 2004) and interpretive skills through visual analogies (Gribas et al., 1996; Misch, 2004). Studying leaf area effect on ET and the relative importance of evaporation and transpiration for ET could also be added to the exercise.

Lessons in OUTREaCH. Students agreed to teach the method and disclose findings to the nursery personnel. During the presentation, students stated that although their findings contributed to a limited quantitative database, more research was needed. They encouraged the nursery participants to adopt the technique summarized in Fig. 1 in their daily work schedule to increase irrigation efficiency (Mathers et al., 2005; Warren and Bilderback, 2005).

Concurrent with the student exercise, the nursery used overhead sprinkler irrigation on 1 -gal pots and 


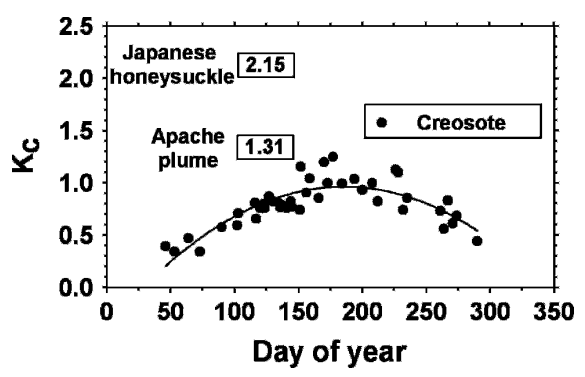

Fig. 4. A 244-d time scale showing dimensionless crop coefficient $\left(K_{c}\right)$ values of potted creosote $(5 \mathrm{gal})$ and of 5-gal apache plume and japanese honeysuckle in the current 22-d study (12 Apr. to 3 May), all under similar experimental conditions at the Fabian Garcia Science Center, Las Cruces, N.M. Data for apache plume and japanese honeysuckle were taken from averages in Table 1 and positioned as values in boxes to approximate their $\mathrm{K}_{\mathrm{c}}$ along the $y$-axis, and at days 102 to 124 of the year along the $x$-axis. The line for creosote is redrawn from Saucedo et al. (2006) under similar experimental conditions. $1 \mathrm{~L}=0.2642$ gal.

microjet irrigation on 5-gal pots of japanese honeysuckle and apache plume, and reported their irrigation rates to the students. At the nursery, sprinkler-irrigated pots were receiving $38 \%$ to $77 \%$ of the full ET as measured by the students, whereas the 5 -gal pots under microjets were receiving more than $100 \%$ of full ET. Therefore, adoption of this gravimetric ET quantification tool by nurseries could prevent overirrigation while also allowing managers to select the lowest irrigation rates possible ("downscaling" of $100 \% \mathrm{ET}$ ) without adversely affecting crop growth and quality. About 1 month after the presentation, Sunland Nursery adopted this technique (Fig. l) on several of their containerized crops, demonstrating a positive impact of information transfer to nursery participants.

During one lecture, students learned that although individual pot weight change is an important value on a spreadsheet, it did not by itself provide a useful measure for nursery block irrigation. Therefore, students expressed ET as depth per unit area to coincide with the irrigation precipitation rate units used at the nursery. During another lecture, students learned the simple equation for using $\mathrm{K}_{\mathrm{c}}$ and reference ET to determine a crop's ET for a given time of year.
This equation allowed the nursery personnel to see how $\mathrm{K}_{\mathrm{c}}$ and reference ET could serve as permanent irrigation scheduling and "metering" tools for a containerized crop. Thus, a structured learning role of the student emerged from in-class instruction, which later merged into an outreach role at the presentation (Fig. 5).

During the panel discussion, the Sunland Nursery production manager explained why this exercise oversimplified a reality of nursery management. For nursery inventory of a single product, the growth stages may vary greatly to permit recurring sales and continuous cash flow. In addition, the nursery's sprinkler-irrigation scaling factors reported by the management $(38 \%$ to $77 \%$ as noted earlier) were not based on actual ET, but were nonetheless resulting in excellent plant quality.

LESSONS IN PARTICIPATORY RESEARCH. Students gained research experience in designing and implementing a small-scale pot water use study. As a learning exercise for both students and nursery personnel, a short period of time was sufficient to demonstrate key concepts of irrigation scheduling, ET, and $\mathrm{K}_{\mathrm{c}}$. However, the relatively high early spring water use of the nursery plants made students appreciate nursery irrigation as a 12-month activity, whereas field crop canopy development was just beginning at this time. Figs. 2 and 3 translated a "maze" of numbers on the spreadsheet into an interpretable form, allowing the students to draw conclusions about species and pot size effects on water use while being guided by a visual analogy (Gribas et al., 1996; Misch, 2004). Visual analogy also allowed participants to conclude that native apache plume has about a $70 \%$ higher relative water use $\left(\mathrm{K}_{\mathrm{c}}\right)$ than does native creosote, at least during the early spring (Fig. 4). In addition, Fig. 4 aided in revealing the ostensibly high early spring average $\mathrm{K}_{\mathrm{c}}$ for the 5 -gal-size japanese honeysuckle compared with the 5gal xeric species. More research could establish seasonal $\mathrm{K}_{\mathrm{c}}$ curves for potted apache plume and japanese honeysuckle to reveal maximum $\mathrm{K}_{\mathrm{c}}$ during peak water demand of summer $(\approx 180-240 \mathrm{~d}$ in Fig. 4$)$.

The exercise demonstrated that xeric plants are opportunistic if water is readily available. Near Las Cruces, desert shrubs can survive on as little as $10 \mathrm{~cm}$ precipitation in 1 year. In the nonlimiting conditions, combined evaporation and transpiration losses from the apache plume study blocks reached $10 \mathrm{~cm}$ in less than 2 weeks and exceeded that of the high ET reference plant for much of the exercise. The data on apache plume may add to published findings on a number of desert-adapted species that use as much water as mesic plants, provided that they are continually irrigated. These species include creosote

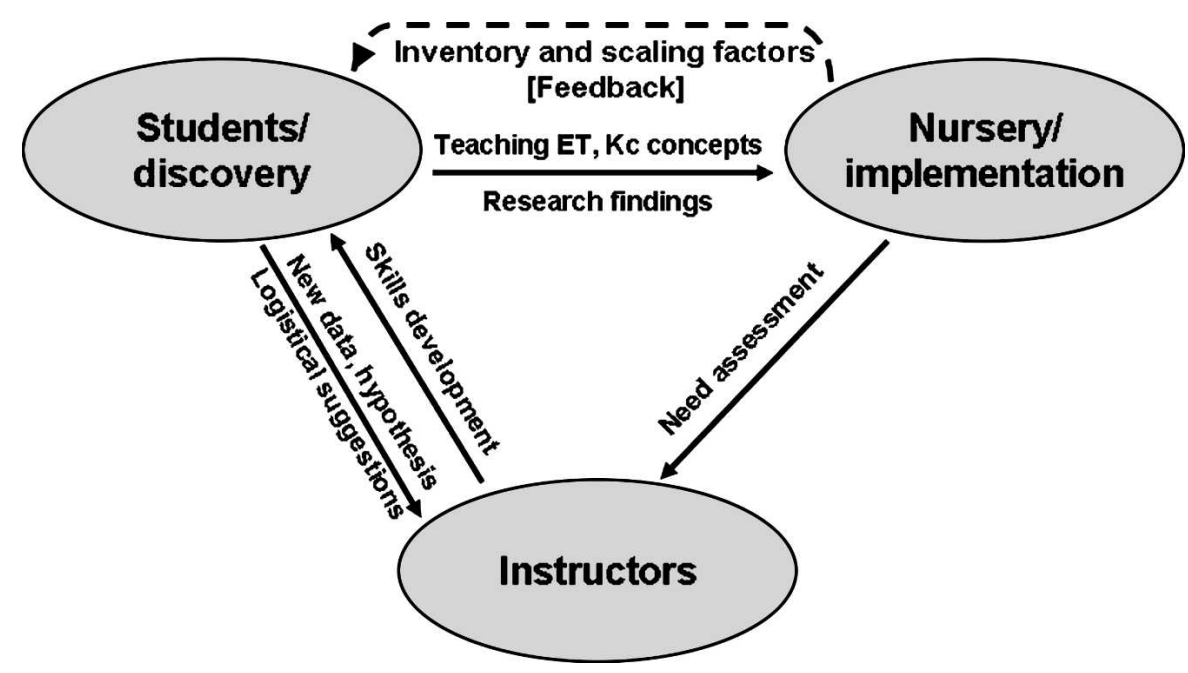

Fig. 5. Information inflow and outflow among instructors, students, and nursery participants. The model represents students as the driving force for information exchange after the initial phases of need assessment and skills development. ET, evapotranspiration; $K_{c}$, crop coefficient. 
(Saucedo et al., 2006), argentine mesquite (Prosopis alba) (Levitt et al., 1995), old man saltbush (Atriplex nummularia) (Glenn et al., 1998), and red river gum (Eucalyptus camaldulensis) (Al-Jamal et al., 2002).

The "feedback" by nursery participants taught the students and instructors that additional research should evaluate effects of different growth stages on water use and effects of deficit irrigation on growth and quality (Fig. 5). In addition, from data in Fig. 4, students suggested that a future class test the hypothesis that apache plume and japanese honeysuckle have higher $K_{c}$ values than creosote at other times of the year besides early spring. Students then offered suggestions for overcoming institutional barriers in attaining 12month $\mathrm{K}_{\mathrm{c}}$ curves, which could allow the testing of this hypothesis (Fig. 5).

\section{Conclusion}

This exercise is readily applicable to undergraduate courses in ornamental plant production, nursery management, and irrigation management. It is relatively simple, can fit within a l-month time frame, has reasonable expectations of students, and emphasizes experiential learning. Other than an electronic balance and routine instructional equipment, the activity is inexpensive and should involve commercial nursery cooperators.

Concerns over the water supply and how it will support growing populations of the southwestern United States have existed for decades. Meanwhile, quantitative data on water requirements of nursery plants have not. The instructors had hoped that for the students, a structured learning role could merge into an effective discovery role, which could later merge into a successful outreach role during the presentation to the nursery. Based on our observations, merging student roles in the undergraduate classroom could be a viable means for addressing a knowledge gap within the "holistic" mission of the university.

\section{Literature cited}

Al-Jamal, M.S., T.W. Sammis, J.G. Mexal, G.A. Picchioni, and W.H. Zachritz. 2002. A growth-irrigation scheduling model for wastewater use in forest production. Agr. Water Mgt. 56:57-79.

American Society of Civil Engineers. 2005. The ASCE standardized reference evapotranspiration equation. 6 June 2006. </www.irrisoft.net/downloads/ literature/ASCE\%20Standardized\%20Equa tion\%20Jan\%202005.pdfs.

Beeson R.C., Jr. 2006. Relationship of plant growth and actual evapotranspiration to irrigation frequency based on management allowed deficits for container nursery stock. J. Amer. Soc. Hort. Sci. 131:140-148.

Dirr, M.A. 1990. Manual of woody landscape plants: Their identification, ornamental characteristics, culture, propagation and uses. Stipes, Champaign, Ill.

Fare, D.C., C.H. Gilliam, and G.J. Keever. 1992. Monitoring irrigation at container nurseries. HortTechnology 2:75-78.

Franco, J.A., J.J. Martinez-Sanchez, J.A. Fernandez, and S. Banon. 2006. Selection and nursery production of ornamental plants for landscaping and xerogardening in semi-arid environments. J. Hort. Sci. Biotechnol. 81:3-17.

Glenn, E., R. Tanner, S. Miyamoto, K. Fitzsommons, and J. Boyer. 1998. Water use, productivity and forage quality of the halophyte Atriplex nummularia grown on saline waste water in a desert environment. J. Arid Environ. 38:45-62.

Gribas, C., L. Sykes, and N. Dorochoff. 1996. Creating great overheads with computers. College Teaching 44:66-68.

Lamb, S.H. 1975. Woody plants of the southwest. Sunstone, Santa Fe, N.M.
Leonard, J.G. and T.F. Patterson. 2004. Simple computer graphing assignment becomes a lesson in critical thinking. Natl. Assn. College Teachers Agr. J. 48:17-21.

Levitt, D.G., J.R. Simpson, and J.L. Tipton. 1995. Water use of two landscape tree species in Tucson, Arizona. J. Amer. Soc. Hort. Sci. 120:409-416.

Mathers, H.M., T.H. Yeager, and L.T. Case. 2005. Improving irrigation water use in container nurseries. HortTechnology 15:8-12.

Misch, D.A. 2004. The interpretive leap: Helping students read between the lines. J. Excellence College Teaching 15:37-61.

New Mexico Climate Center. 2006. Climate data retrieval pages. 6 June 2006. <http://weather.nmsu.edu/ data/data.htm $>$.

Picchioni, G.A., S.A. Weinbaum, D.L. Daniel, and H. Karaca. 2000. Biological and practical importance of light microenvironments in a tree: Participatory research to match teaching and learning styles. J. Natural Resources Life Sci. Educ. 29:78-87.

Picchioni, G.A., M. Valenzuela-Vázquez, and S. Armenta-Sanchez. 2001. Calciumactivated root growth and mineral nutrient accumulation of Lupinus havardii Wats.: Ecophysiological and horticultural significance. J. Amer. Soc. Hort. Sci. 126:631-637.

Ruiz, A., T.W. Sammis, G.A. Picchioni, J.G. Mexal, and W.A. Mackay. 2006. An irrigation scheduling protocol for treated industrial effluent in the Chihuahuan Desert. J. Amer. Water Works Assn. 98:122-133.

Saucedo, D., T.W. Sammis, G.A. Picchioni, and J.G. Mexal. 2006. Wastewater application and water use of Larrea tridentata. Agr. Water Mgt. 82:343-353.

Warren, S.L. and T.E. Bilderback. 2005. More plant per gallon: Getting more out of your water. HortTechnology 15 : 14-18. 